\title{
PEMBELAJARAN PAI BERBASIS MOVING CLASS DI SMP NEGERI 1 GUDO JOMBANG
}

\author{
Moch. Sya'roni Hasan \\ STIT Al-Urwatul Wutsqo Jombang, Indonesia \\ Email: ronistit@yahoo.com \\ Dian Eka Saputri \\ STIT Al-Urwatul Wutsqo Jombang, Indonesia \\ Email: dian6631@gmail.com
}

\begin{abstract}
Moving Class is one of the learning models that moves between classes or places of study. This learning model is applied to the learning of Islamic religious education in SMP Negeri 1 Gudo. The purpose of this study is to describe the implementation of the Moving Class in the learning of Islamic Religious Education in SMP Negeri 1 Gudo Jombang. Thus the conclusions of the results of the study are: The Implementation of Moving Classes in Islamic Religious Education learning in SMP Negeri 1 Gudo is one of the efforts to create a new learning process, so that it is not saturated because of the monotony and routine of providing unchanging facilities (classrooms). This junior high school located in Gudo has a goal in implementing moving classes in Islamic religious education learning, which is to change the awkward learning atmosphere to be active, students can argue and can directly practice the material conveyed by the teacher. In learning Islamic religious education a lot of theories that need to be developed, therefore not only understanding the theory, but is also expected to be able to apply in life in society.
\end{abstract}

Keywords: PAI Learning, Moving Class.

Abstrak: Moving Class merupakan salah satu model pembelajaran yang berpindah kelas atau tempat belajar. Model pembelajaran ini di terapkan pada pembelajaran pendidikan agama islam di SMP Negeri 1 Gudo. Adapun tujuan penelitian Ini untuk mendiskripsikan implementasi Moving Class pada pembelajaran Pendidikan Agama Islam di SMP Negeri 1 Gudo Jombang. Dengan demikian kesimpulan dari hasil penelitian yaitu: Pelaksanaan Moving Class pada pembelajaran Pendidikan Agama Islam di SMP Negeri 1 Gudo merupakan salah satu usaha untuk menciptakan proses pembelajaran baru, agar tidak jenuh karena monoton dan rutinitas dari penyediaan sarana (ruang kelas) yang tidak berubah. Sekolah menengah pertama yang berada di Gudo ini memiliki tujuan dalam penerapan moving class pada pembelajaran pendidikan agama islam yaitu merubah suasana belajar yang canggung menjadi aktif, peserta didik dapat berargumen dan dapat mempraktekkan secara langsung materi yang di sampaikan oleh guru. Dalam belajar pendidikan agama islam banyak sekali teori yang perlu di kembangkan, oleh karena itu tidak sekedar memahami teori, namun diharapkan juga bisa mengaplikasikan dalam kehidupan di masyarakat.

Kata Kunci: Pembelajaran PAI, Moving Class. 


\section{Pendahuluan}

Peran Pendidikan dalam kemajuan bangsa adalah sebagai sarana untuk membangun dan membentuk karakter bangsa. Sehingga jika masyarakat suatu bangsa memiliki kecerdasan yang tinggi maka akan menimbulkan suasana dan nuansa kehidupan cerdas pula, begitupun juga sebaliknya. Selain itu, Pendidikan juga berperan mengembangkan kemandirian dan membentuk sikap bekerja keras pada masyarakat itu sendiri. ${ }^{1}$ Pada zaman sekarang ini, setiap Lembaga pendidikan seharusnya sudah melakukan sebuah pembaharuan atau inovasi untuk menyiapkan siswa yang mempunyai SDM yang berkualitas. Hal ini bisa dimulai dengan membuat kreasi dan inovasi dalam kegiatan belajar mengajar di kelas. Salah satu cara yang dapat dilakukan adalah dengan melakukan model pembelajaran berbasis moving class.

Menurut Sagala, Moving class merupakan model pembelajaran yang digunakan untuk menciptakan kegiatan yang aktif dan kreatif, dimana sistem belajar mengajarnya peserta didik mendatangi Guru di kelas, bukan Guru yang mendatangi peserta didik di kelas. Model Pembelajaran moving class, tiap guru mempuyai kelas pribadi, sehingga peserta didik yang akan mengikuti proses belajar mengajar harus berpindah dari satu kelas ke kelas lain. Sehingga, terdapat penamaan kelas berdasarkan bidang studi, setiap kali subyek pelajaran berganti maka peserta didik akan meninggalkan kelas dan mendatangi kelas lainya sesuai bidang studi yang dijadwalkan. ${ }^{2}$ Agar pelaksanaan moving class dalam pembelajaran bisa sukses, kuncinya adalah kedisiplinan. Baik disiplin waktu yaitu kedatangan guru dan murid, juga disiplin dalam melaksanakan tugas secara professional.

SMP Negeri 1 Gudo Jombang telah melakukan suatu sistem belajar mengajar dengan cara menerapkan model pembelajaran moving class pada pembelajaran PAI. Dalam proses pembelajarannya lebih menekankan pada pembentukan kepribadian Islami. Sehingga peserta didik tidak hanya mampu mempelajari pembelajaran PAI tetapi juga bisa mempraktekan dan mengamalkan dalam kehidupan sehari hari. ${ }^{3}$ Dengan diterapkannya model moving class ini, peserta didik diharapkan bersemangat dan termotivasi ketika mengikuti proses pembelajaran. Sehingga dengan adanya model pembelajaran moving class pada mata pelajaran PAI, bisa menjadikan anak tidak jenuh dan mampu mengikuti proses belajar mengajar dengan baik, sehingga tujuan pembelajaran tercapai.

Penelitian ini bertujuan untuk mendiskripsikan implementasi Moving Class pada pembelajaran Pendidikan Agama Islam di SMP Negeri 1 Gudo Jombang. Sedangkan metode penelitiannya menggunakan pendekatan kualitatif dengan jenis penelitian studi kasus. Metode pengumpulan data dilakukan melalui wawancara, observasi dan dokumentasi. ${ }^{4}$ Teknik analisis data yang digunakan adalah reduksi data, data display dan verifikasi. Sedangkan untuk mengecek keabsahan data meliputi perpanjangan pengamatan, ketekunan penelitian dan trianggulasi. ${ }^{5}$

\footnotetext{
${ }^{1}$ E. Mulyasa, Manajemen Berbasis Sekolah, (Bandung; Remaja Rosdakarya, 2002), 4.

${ }^{2}$ Syaiful Sagala, Kemampuan Profesional Guru dan Tenaga Pendidikan, (Bandung: Alfabet, 2009), 183.

${ }^{3}$ Moch. Sya'roni Hasan Dan Nikmawati, Model Pembelajaran PAI dalam Membentuk Kepribadian Islami Siswa di SMK Dr Wahidin Sawahan Nganjuk, Ta'lim: Jurnal Studi Pendidikan Islam Vol 3 No 1 (2020): January), 2.

${ }^{4}$ Emzir, Metodologi Penelitian Kualitatif Analisis Data (Jakarta: Rajagrafindo Persada, 2014), 37.

${ }^{5}$ Sugiyono. Metode Penelitian Pendidikan (Pendekatan Kuantitatif, Kualitatif, Dan ReD), (Bandung: Alfabeta. 2013),
} 


\section{Hasil Penelitian}

Setelah melakukan penelitian di lapangan, penulis akan memaparkan hasil dari penelitian yang diambil dari berbagai metode observasi, wawancara dan dokumentasi. Berikut hasil yang diperoleh dari penelitian selama berada di lapangan.

1. Latar belakang adanya Implementasi Moving Class pada pembelajaran PAI di SMP Negeri 1 Gudo Jombang

Penulis melakukan observasi, penulis melihat pada saat mata pelajaran PAI peserta didik melakukan proses pembelajarannya berada di luar kelas, dikarenakan SMP Negeri 1 Gudo adalah sekolah yang menerapkan model pembelajaran yang bervariasi, salah satunya adalah menerapkan Moving Class pada pembelajaran Pendidikan agama islam, karena denganadanya model, strategi, dan metode pembelajaran yang bervariasi dapat mempengaruhi tingkat kepahaman peserta didik dalam menerima materi yang diajarkanoleh guru, sehingga perlu adanya model pembelajaran yang tepat dan mudah dipahami oleh peserta didik agar nantinya pesertadidik dapat mengaplikasikan materi dalam kehidupan di masyarakat. Hal tersebut sesuai dengan pernyataan yang disampaikan oleh Bapak Kepala Sekolah SMP Negeri 1 Gudo:

"Sebagai kepala sekolah, saya mengamati proses pembelajaran seluruh mata pelajaran di
sekolah ini, tidak terkecuali proses pembelajaran PAI, dulu saya melihat anak-anak ketika
menerima pelajaran Pendidikan agama islam dengan hanya mendengar atau biasa di sebut
metode ceramah, peserta didik akan cepat jenuh dan setiap harinya mereka menerima
pelajaran di dalam suatu ruangan yang tetap dari pagi sampai siang. Oleh sebab itu sejak di
bangunnya mushola di SMP Negeri l Gudo maka sejak saat itu di terapkan proses
pembelajaran Pendidikan agama islamdengan Model Moving Class atau pindah kelas, yakni
melakukan pembelajarannya di mushola". (Kepala Sekolah. 2018, 28 Agustus)

Penyampaian Bapak Madsilah,SP.d di atas senada dengan pernyataan Ibu Siti Fadlilah, S.Ag selaku guru PAI di SMP Negeri 1 Gudo, yang menggambarkan penerapan Moving Class pada pembelajaran Pendidikan agama Islam

"Di SMP Negeri 1 Gudo ini sudah lama menerapkan pembelajaran Pendidikan agama islam dengan Moving Class atau pindah kelas yakni ke mushola, di karenakan peserta didik yang dari pagi menerima pelajaran di kelas biasanya pada jam jam akhir akan merasa bosan, sebab hanya mendengarkan proses pembelajaran dengan ceramah yang di terima dengan duduk dengar diam saja dan juga di ruangan yang sama dari pagi sampai siang" (Siti Fadlilah S,A.g, Guru PAI, 2018, 30 Agustus)

Pernyataan di atas yang disampaikan oleh Ibu Siti Fadlilah S.Ag, salah satu guru Pendidikan agama islam di SMP Negeri 1 Gudo sesuai dengan pernyataan Jihan, siswa klas 8G SMP Negeri 1 Gudo yang menyatakan bahwa:

"Pembagian jam pelajaran Pendidikan agama islamsetiap kelas pasti beda-beda, ada yang dapat jam pagi ada yang siang, yang dapat siang itu biasanya sudah mulai bosan dalam menerima pelajarannya, terkadang teman-teman alasan izin ke toilet supaya tidak jenuh di kelas, namun semenjak di terapkannya Moving Class pada pembelajaran Pendidikan agama islam yang di ajak ke mushola, teman-teman mulai semangat dalam proses pembelajarannya, saat melakukan pembelajaran di mushola dalam menerima pelajarannyapun juga terkesan santai, karena ruangannya luas dan bisa memilih untuk duduk dimana saja, namun tidak lupa tetap fokus pada proses pembelajarannya"(Jihan, siswa. 2018, 2 September) 
2. Tujuan Moving Class pada pembelajaran PAI di SMP Negeri 1 Gudo Jombang

Dengan adanya Moving Class pada pembelajaran Pendidikan agama islam adalah untuk merubah suasana belajar yang canggung menjadi aktif, para peserta didik dapat berargumen dan dapat mempraktekkan secara langsung materi yang telah di sampaikan oleh gurunya, Hal ini berdasarkan wawancara pada Bapak Madsilah S.Pd selaku kepala SMP Negeri 1 Gudo

"Moving Class yang di terapkan di SMP Negeri 1 Gudo ini adalah suatu pembelajaran yang berpindah ke mushola, yang di khususkan pada pembelajaran Pendidikan agama islam, karena dalam belajar Pendidikan agama islam banyak sekali teori yang membutuhkan praktek yang perlu di kembangkan, dan di harapkan juga kelak peserta didik bisa mengaplikasikannya di lingkungan masyarakat setempat, karena merekalah yang akan menjadi generasi penerus muda yang di harapkan masyarakat bisa menjadi teladan yang baik" (Kepala Sekolah. 2018, 28 Agustus)

Keterangan kepala sekolah di atas di perkuat oleh pernyataan Bapak Misbahul Munir, S.Ag selaku guru Pendidikan agama islam di SMP Negeri 1 Gudo

"Dalam pelajaran Pendidikan agama islam memang banyak teori yang harus di pahami, namun peserta didik juga perlu dan harus bisa untuk mempraktekkan secara langsung baik di sekolah maupun di masyarakat, oleh karena itu mengajak peserta didik melakukan pembelajaran di mushola agar tidak jenuh di dalam kelas saja, namun tujuan lainnya adalah supaya peserta didik bisa langsung mempraktekkannya seperti materi bersuci, sholat, adzan dsb"(Guru 1 PAI, 2018, 2 September)

Pernyataan tujuan di terapkan Moving Class pada pembelajaran Pendidikan agama islam di atas juga di sampaikan oleh salah satu siswa kelas $8 \mathrm{G}$ sebagai berikut:

"Di terapkannya Moving Class pada pembelajaran Pendidikan agama islam ini adalah menciptakan suasana pembelajaran yang aktif, bila menerima teori yang harus di pahami saja teman-teman terkadang mudah lupa materinya, tapi di sini setelah memahami materi yang di sampaikan oleh guru teman-teman langsung di suruh mempraktekkannya, seperti materi sholat fardhu, sholat sunnah dsb, ketika belajarnya di mushola kita langsung bisa praktek sholat. Jadi teman-teman semua tidak hanya diam menerima materi saja beberapa jam, namun teman-teman langsung bisa mempraktekkan seketika waktu itu, karena pelajaran Pendidikan agama islam tidak hanya ada ujian teori saja, tapi ada juga ujian prakteknya. Apalagi bila sudah kelas sembilan, banyak ujian prakteknya." (Siswa kelas 8G, 2018, 2 September)

Mengenai tujuan Moving Class pada pembelajaran Pendidikan agama islam adalah membuat suasana belajar yang aktif, dan juga peserta didik tidak hanya memahami materi yang di sampaikan guru, namun peserta didik bisa langsung mempraktekkan materimateri yang ada pada pelajaran Pendidikan agama islam dan di harapkan peserta didik juga dapat mempraktekkannya dalam lingkungan masyarakat kelak.

\section{Perencanaan Moving Class pada pembelajaran PAI di SMP Negeri l Gudo Jombang.}

Berdasarkan hasil wawancara dengan bapak kepala sekolah, dalam tahap perencanaan Moving Class pada pembelajaran Pendidikan agama islamyaitu sesuai dengan tujuan pendidikan di mana pendidikan di tuntut sebagai suatu wadah untuk mengasuh anak dengan baik dan juga untuk di kembangkan, yang nantinya dapat memenuhi kebutuhan untuk diri sendiri maupun orang lain. Seorang pendidik seharusnya menyusun aktifitas pembuka dalam proses pembelajaran, karena dengan adanya itu akan menjadikan siswa merasa lebih leluasa ikut berfikir dan memperhatikanpelajaran. Hal tersebut sebagaimana dijelaskan oleh guru Pendidikan agama Islam. 
"Sebelum melaksanakan proses pembelajaran pendidikan agama islam, terlebih dahulu saya membuat RPP yang mana isinya akan menjelaskan beberapa langkah langkah dalam proses pembelajaran di mana terdapat model dan metode pembelajaran, dalam perencanaa pembelajaran ini saya dan guru-guru lainnya sangat memperhatikan hal ini agar bisa di terapkan seoptimal mungkin dan bisa terlaksana dengan baik."(Guru PAI, Guru, 20184 September)

Mengenai perencanaan yang di sampaikan oleh Guru PAI di atas sejajar dengan pernyataan Bu Ida Nurrohmah selaku waka kurikulum di SMP Negeri 1 Gudo, berikut pernyataanya:

"Sebelum seorang guru melakukan pembelajaran memang seharusnya mempersiapkan beberapa langkap-langkah yang nantinya akan di terapkan pada saat proses pembelajaran tersebut, dengan membuat RPP, merancang model dan juga metode yang akan di terapkan dalam menyampaikan materi ke peserta didik."

Pernyataan yang di sampaikan oleh Waka Kurikulum di perkuat oleh hasil wawancara kepada Bapak kepala sekolah SMP Negeri 1 Gudo, berikut pernyataannya:

"Setiap kegiatan belajar mengajar akan di lakukan, seluruh guru memang harus terlebih dahulu merencanakan proses pembelajarannya, bagaimana langkah-langkah yang akan di terapkan dalam proses pembelajaran, bagaimana model yang akan di terapkan, dan juga bagaimana metode yang akan di gunakan dalam proses penyampaian materi pada peserta didik, entah dengan diskusi atau dengan metode demonstrasi dll yang nantinya semua itu berada pada RPP. Karena suatu yang di rencanakan dengan optimal maka akan berjalan dengan baik." (Waka Kurikulum, Kepala Sekolah. 2018, 28 Agustus).

\section{Pelaksanaan Moving Class pada pembelajaran PAI di SMP Negeri 1 Gudo Jombang.}

Berdasarkan wawancara kepada kepala sekolah, guru dan juga peserta didik mengenai pelaksanaan pembelajaran Moving Class dapat di paparkan sebagai berikut, berikut hasil wawancara kepada kepala sekolah SMP Negeri 1 Gudo.

"Dalam pelaksanaan Moving Class di SMP Negeri 1 Gudo ini bisa di bilang seluruh peserta didik menyukai dengan pembelajaran yang di pindah di mushola, khususnya pada pembelajaran Pendidikan agama islam. Moving Class tidak hanya bisa di laksanakan di LAB atau kelas, melainkan bisa di laksanakan di mushola pribadi sekolah, perpustakaan, dan tempat-tempat yang lain yang masih berhubungan dengan sekolah dan juga sesuai bila di gunakan untuk proses pembelajaran, karena harapannya di sini untuk membuat proses pembelajaran aktif dan menumbuhkan keaktifan peserta didik dalam pelajarannya, dalam pelaksanaan Moving Class yang di terapkan pada pembelajaran pendidikan agama islam ini, secara menyeluruh saya serahkan kepada guru Pendidikan agama islam untuk mengatur bagaimana Moving Class dapat terlaksana dengan sukses" (Kepala Sekolah. 2018, 1 September)

Selain wawancara langsung pada bapak kepala sekolah, peneliti juga melakukan wawancara pada guru Pendidikan agama islam yang menjelaskan bagaimana proses pelaksanaan Moving Class di SMP Negeri 1 Gudo.

"Pelaksanaan pembelajaran Moving Class di sini di mulai pada saat bel pergantian jam pelajaran, peserta didik melakukan perpindahan dari kelas ke musholla secara bersamasama agar tidak ada waktu yang sia-sia, dan juga demi keberlangsungan materi pelajaran, agar sesuai dengan waktu rencana pembelajaran yang sudah di tentukan. Bagi peserta didik yang datangnya terlambatakan di beri sedikit hukuman berupa berdiri di depan temantemannya, pemberian sangsi tersebut agar mereka yang terlambat merasa malu dan di lain hari tidak mengulanginya lagi, serta sebagai contoh yang lain agar tidak terlambat, dan juga melatih disiplin waktu." (Guru PAI, 2018, 3 September) 
Pernyataan tersebut di perkuat dengan penjelasan salah satu peserta didik kelas VII SMP Negeri 1 Gudo.

"Sejak dulu memang kalau pembelajaran Pendidikan agama islam di mushola itu selalu ada yang datangnya terlambat, karena waktu bel pergantian jam tidak hanya 1 kelas yang keluar untuk perpindahan Kegiatan belajar mengajar, namun ada beberapa kelas, terkadang temanteman ada yang ke toilet, juga ada yang masih membereskan semua perlengkapan sekolahnya dll untuk yang pembelajaran. Namun di siplin waktu tetap di terapkan, oleh karena itu siapapun yang datangnya terlambat sampai 5 menit lebih di beri sangsi berdiri 20 menit di depan teman-teman sambil mengikuti pelajaran, dengan di berikannya sangsi dari bu fadlilah untuk yang datang terlambat teman-teman yang dulunya sering terlambat mengikuti pelajaran pelan -pelan mulai berkurang yang terlambat." (Siswa Kelas VII A, 2018, 4 September)

Wawancara mengenai pelaksanaan Moving Class pada pembelajaran Pendidikan agama islam juga di dapat dari penjelasan Bapak Misbahul Munir, selaku guru Pendidikan agama islam di SMP Negeri 1 Gudo, berikut penjelasannya

"Untuk menerapkan Moving Class di pembelajaran Pendidikan agama islam ini, saya dan beberapa guru Pendidikan agama islam lainnya telah menerapkan beberapa tekhnik untuk melaksanakan Moving Class pada pembelajaran Pendidikan agama islam ini, agar peserta didik tetap fokus dalam kegiatan pembelajaran, sekolah telah menyediakan LCD di dalam mushola untuk menfasilitasi proses KBM. Sehingga peserta didik akan lebih memperhatikan pada materi yang akan di pelajari, dan juga bisa menayangkan beberapa video yang bisa menstimulasi peserta didik sebelum memulai pelajaran. Di sinilah letak pembelajaran yang menjadikan suasana pasif menjadi aktif, karena peserta didik melakukan KBM di mushola yang di katakan pembelajaran menyenangkan dan di fasilitasi LCD yang menunjang proses pembelajarannya."( Guru PAI 2, 2018, 2 September)

Pernyataan Bapak Misbahul Munir di atas di perkuat oleh salah satu peserta didik kelas delapan, berikut pernyataannya

"Teman-teman semua memang sangat suka jika pembelajarannya di lengkapi dengan LCD, baik di kelas maupun di LAB bahkan di perpustakan juga terdapat LCD untuk menunjang pembelajaran yang di laksanakan di perpustakaan, di musholapun juga tidak ketinggalan, oleh Bapak Madsilah di sediakan LCD untuk pembelajaran Pendidikan agama islam yang di laksanakan di mushola, dengan di tayangkan beberapa materi di LCD saya dan teman-teman lebih fokus untuk menerima pelajaran yang di sampaikan oleh guru, tidak hanya sekedar materi yang di tayangkan, tapi beberapa video yang akan menjadi bahan praktek dalam pelajaran Pendidikan agama islam juga langsung di tayangkan, beda kalau hanya melihat buku serta gambar-gambar, teman-teman sering bosan." (Salis Rahmania, Siswa, 2018, 5 September 2018)

\section{Ibu Siti Fadlilah S.Ag juga menambahkan sedikit pernyataan}

"Yang melaksanakan pembelajaran Pendidikan agama islam di mushola tidak hanya satu kelas saja, jadi apabila di dalam mushola sudah ada yang menggunakan, anak-anak bisa melakukan pembelajarannya di serambi depan atau samping, yang terpenting dan saya usahakan anak-anak tetap melakukan pembelajaran di mushola, meski tidak selalu dapat di dalam yang terdapat LCD nya, namun anak-anak tetap saya buat untuk semangat dalam pembelajaran, dengan mengajak untuk diskusi kelas atau kelompok yang bisa menumbuhkan rasa keakraban dan juga berani mengeluarkan ide-ide, serta mengajukan pertanyaan yang bisa di jadikan dialog diskusi untuk peserta didik" (Guru PAI, 2018, 3 September)

Salah satu siswa juga memperkuat pernyataan Ibu Siti Fadlilah S.Ag dengan menjelaskan alasan lebih senang mengajak pembelajaran di mushola untuk pelajaran Pendidikan agama islam. 
"Meski tidak dapat pergantian kelas di mushola yang dalam, saya dan teman-teman bisa melakukan pembelajaran di serambi depan atau samping mushola, meski tidak ada LCD nya tapi bu fadlilah selalu memberikan proses pembelajaran terasa semangat, bu fadlilah mengawali pembelajarannya dengan tanya jawab seputar pembelajaran yang lalu dan menyambungkan ke materi yang akan di bahas, bu fadlilah juga selalu membuat suasana pembelajaran terasa menyenangkan, terkadang membuat pola duduk melingkar, kotak, dan juga terkadang membuat sebuah kelompok-kelompok kecil untuk menjadikan saling berkolaborasi antara temannya sehingga mengerjakan tugas secara bersama dalam kelompok kecil.(Siswa Kelas 8A, 20185 September)

Dalam pelaksanaan sistem Moving Class pada pembelajaran pendidikan agama islam ini guru harus memahami dan juga mengerti bagaimana agar Moving Class ini dapat terlaksana dan harapan bersama dapat tercapai keaktifan dalam belajar dan juga peserta didik berkembang dengan baik, Moving Class sendiri tidak hanya di laksanakan dengan berpindah dari kelas satu ke kelas lainnya, akan tetapi dapat di laksanakan di masjid atau mushola, perpustakaan, LAB dan tempat-tempat yang lain selama masih berhubungan dengan lingkungan sekolah dan juga mendukung untuk di gunakan proses kegiatan belajar mengajar.

\section{Evaluasi Moving Class pada pembelajaran PAI di SMP Negeri 1 Gudo Jombang.}

Tahap terakhir dalam pembelajaran adalah evaluasi pembelajaran. Berikut adalah hasil wawancara dengan beberapa pihak mengenai evaluasi Moving Class pada pembelajaran pendidikan agama islam di SMP Negeri 1 Gudo, hal tersebut sama halnya diutarakan oleh Bapak Kepala Sekolah SMP Negeri 1 Gudo.

"Evaluasi dalam pelaksanaan Moving Class pada pembelajaran pendidikan agam islam di lakukan untuk menilai sejauh mana tingkat kecapaian dalam penerapannya dan juga apa saja yang harus di perbaiki untuk menjadikan suatu pembelajaran agar lebih optimal bahkan bisa di katakan sukses. Untuk itu saya selaku kepala sekolah dalam melakukan evaluasi ini mengajak seluruh guru untuk melakukan rapat membahas kendala yang di alami selama proses pembelajaran, meningkatkan kinerja guru supaya bisa menjadi contoh yang baik bagi peserta didik." (Kepala Sekolah. 2018, 1 September)

Peneliti juga melakukan wawancara kepada Bapak Misbahul Munir, S.Ag selaku guru pendidikan islam di SMP Negeri 1 Gudo yang menjelaskan bagaimana Evaluasi dalam penerapan Moving Class pada pembelajaran pendidikan agama Islam

"Untuk evaluasi pada pembelajaran pendidikan agama islam yang di terapkan dengan Moving Class ini biasanya ketika pelajaran sudah selesai di sampaikan oleh guru, peserta didik akan di beri kesempatan untuk bertanya yang belum di mengerti, apabila tidak ada pertanyaan maka guru akan sekilas memberikan pertanyaan-pertanyaan untuk mengetahui sejauh mana pemahaman peserta didik dalam menerima pelajaran pada saat itu, tidak lupa juga ada evaluasi lewat ulangan harian, ulangan tengah semester dan ulangan akhir semester." (Guru PAI 2, 20184 September)

Pernyataan di atas di perkuat oleh wawancara kepada Guru PAI 1 selaku guru pendidikan agama islam di SMP Negeri 1 Gudo.

"Dalam tahap evaluasi pembelajaran pendidikan agama islam ini ada beberapa yang bisa di lakukan, memberikan tugas individu memberikan tugas kelompok yang biasanya di kerjakan bersama di rumah salah satu temannya, ada tes lisan dan juga ada tes essai, yang mana tes lisan dan tes essai ini sangatlah penting di lakukan, karena sedikit banyak untuk mengetahui sejauh mana pemahaman peserta didik, karena pembelajaran pendidikan islam tidak hanya nilai teori yang perlu di perhatikan, namun juga nilai praktek yang di terapkan setelah peserta didik menerima pelajaran. (Guru PAI 1, 20183 September) 
Bapak Kepala Sekolah juga menambahkan sedikit penjelasan mengenai evaluasi yang harus di lakukan guru.

"Evaluasi tidak hanya di lakukan di akhir pembelajaran atau di tengah semester bahkan di akhir semester, namun dalam mengevaluasi proses pembelajaran bisa di lakukan melalui tanya jawab antara guru dan peserta didik kapan saja, entah pada saat di mulai pembelajaran dengan memberikan pertanyaan-pertanyaan tentang materi minggu lalu dan juga untuk mengetahui daya ingat peserta didik. Dengan memberi pertanyaan itu, bisa menjadi proses evaluasi lisan dan juga dapat mengetahui apakah benar-benar sudah di terapkan atau belum dalam kehidupan sehari-hari oleh peserta didik." (Kepala Sekolah, 2018 3 September)

Mengenai penjelasan evaluasi Moving Class pada pembelajaran pendidikan agama islam di atas, juga di dukung hasil dari wawancara salah satu peserta didik, berikut penjelasannya

"Setiap pembelajaran pendidikan agama islam selesai 1 atau 2 bab materi tersampaikan, $\mathrm{Bu}$ Fadlilah maupun Bapak Munir selalu mengadakan ulangan harian, ada tes essai dan juga tes lisan, tes essai di lakukan dengan memberi soal-soal yang terdiri dari pilihan ganda dan juga uraian, tes lisannya di lakukan dengan memberi pertanyaan-pertanyaan yang langsung bisa di jawab oleh seluruh teman - teman, terkadang tes lisannya di lakukan maju satu kelompok, terkadang satu satu maju gantian di beri pertanyaan, kadang juga bu fadlilah mengadakan tanya jawab sebagai tes lisan yang nantinya siapa yang bisa menjawab lebih cepat akan mendapat nilai tambahan." (Siswa, 20182 September)

Pada tahap evaluasi penerapan Moving Class pada pembelajaran pendidikan agama Islam ini, guru melakukan beberapa hal dalam mengevaluasi, melalui tugas individu, kelompok, juga mengadakan tes essai dan tes lisan oleh seluruh peserta didik setelah materi tersampaikan.

Tes essai atau mengambil nilai dari hasil belajar peserta didik di lakukan melalui ulangan harian, ulangan tengah semester, maupun ulangan akhir semester. Tes lisan di lakukan untuk mengetahui daya ingat peserta didik dalam mengingat pelajaran yang sudah lewat tersampaikan.

\section{Faktor pendukung Moving Class pada pembelajaran PAI di SMP Negeri 1 Gudo Jombang.}

Berikut wawancara yang di lakukan oleh peneliti dengan kepala sekolah mengenai faktor pendukung sistem Moving Class pada pembelajaran pendidikan agama Islam di SMP Negeri 1 Gudo sebagai berikut :

"Faktor pendukung pada pembelajaran Moving Class yang di terapkan pada pelajaran pendidikan agama islam ini merupakan sesuatu yang dapat mendorong atau mempengaruhi peserta didik dalam meningkatkan pembelajarannya untuk menjadi lebih baik, dalam melaksanakan Moving Class pada pembelajaran pendidikan agama islam di SMP Negeri 1 Gudo ini salah satunya faktor pendukungnya yaitu komitmen dari pihak sekolah untuk menciptakan suasana belajar yang menyenangkan, terkesan santai namun tetap fokus pada materi, serta meningkatkan kualitas dalam kegiatan belajar mengajar." (Kepala Sekolah, 20183 September)

Pernyataan kepala sekolah di atas senada dengan pernyataan Guru PAI 2 mengenai faktor pendukung Moving Class pada pembelajaran pendidikan agama islam.

"Faktor pendukung dalam pelaksanaan Moving Class pada pembelajaran pendidikan agama islam ini yaitu dari kesepakatan seluruh pihak sekolah dan staff lainnya, yakni bagaimana seorang guru dalam kegiatan belajar mengajarnya semakin berkualitas dan peserta didik semakin antusias dalam proses menerima pelajaran. Karena tingkat kualitas seorang guru 
akan mempengaruhi tingkat pemahaman peserta didik. Sehingga bagaimana caranya agar peserta didik dapat menerima pelajaran dengan nyaman dan juga cepat tanggap khususnya pada pelajaran pendidikan agama islam yang nantinya akan mereka terapkan di masyarakat." (Guru PAI 2, 20184 September) Gudo.

Pernyataan dari guru PAI 2 juga di perkuat oleh salah satu peserta didik SMP Negeri 1

"Faktor pendukung dalam pelaksanaan Moving Class pada pembelajaran pendidikan agama islam di sini sesuai dengan visi SMP Negeri 1 Gudo yakni berbudaya, berprestasi, beriptek dan berwawasan lingkungan yang berlandaskan iman dan taqwa, dari situ saya dan temanteman sedikit banyak akan berusaha untuk menjadi seorang yang bisa beriptek yang berlandaskan iman dan taqwa, dengan cara mencari ilmu dengan sungguh-sungguh, karena pendidikan islam tidak hanya sekedar mengetahui materi namun juga harus bisa menerapkan dalam kehidupan sehari-hari.

Mengenai faktor pendukung yang lainnya juga di dapat berdasarkan hasil wawancara dari Guru PAI 1 selaku guru pendidikan agama islam di SMP Negeri 1 Gudo.

"Untuk faktor pendukung dari di terapkannya Moving Class pada proses pembelajaran pendidikan agama islam di sini juga bangunan mushola yang setiap harinya di jadikan tempat di terapkannya Moving Class pada pembelajaran pendidikan agama islam, seperti di katakan di awal bahwasannya pelajaran pendidikan agama islam ini peserta didik tidak hanya sekedar mengerti teori namun juga di harapkan bisa mempraktekkan materi yang sudah di sampaikan oleh guru dan juga dapat mengaplikasikan dalam kehidupan seharihari. Oleh karena itu guru harus bisa menjadikan pembelajaran hidup atau aktif dan juga mengelola dengan suasana kondusif sehingga peserta didik dapat menerima dengan nyaman dan tanggap dalam proses menerima materi yang di sampaikan oleh guru."(Guru PAI 1, 2018 3 September)

Pernyataan Guru PAI 1 di atas di dukung oleh pernyataan salah satu peserta didik sebagai berikut:

"Mushola pribadi yang terletak di dalam lingkungan SMP Negeri l Gudo ini memang setiap harinya di buat untuk melaksanakan ibadah oleh guru, peserta didik dll, namun selain di buat ibadah, mushola ini juga sebagai tempat di terapkannya Moving Class atau perpindahan kelas pada proses pembelajaran pendidikan agama islam, bila pelajaran TIK melakukan pembelajarannya di LAB komputer, bila pelajaran bahasa indonesia melakukan pembelajarannya di LAB bahasa, maka pelajaran pendidikan agama islam pun bisa di lakukan di mushola, karena fasilitas pun juga tidak kalah dengan LAB, karena setelah teman-teman menerima materi dari guru, ketika guru menyuruh untuk mempraktekkannya, teman-teman langsung bisa mempraktekannya saat itu juga."(Siswa, 20185 September)

Mengenai fasilitas yang berada di beberapa LAB maupun di beberapa tempat yang bisa di jadikan proses pembelajaran, peneliti juga mendapatkan pernyataan dari Bapak bagian pemeliharaan sarana dan prasarana di SMP Negeri 1 Gudo, berikut pernyataannya :

"Untuk sarana dan prasarana dalam menunjang pembelajaran di sini memang terbilang cukup dalam arti setiap kelas sudah terdapat papan tulis yang menggunakan kapur maupun spidol dan juga papan untuk menayangkan LCD, namun untun LCD masih ada beberapa yang di letakkan di ruang khusus, jadi bila pembelajarannya membutuhkan LCD sebagai penunjang pembelajaran maka bisa di gunakan di dalam kelas, tapi untuk LAB komputer dan Lab bahasa di dalam kelasnya sudah ada LCD yang siap pakai langsung, untuk yang pembelajarannya di mushola memang sudah di sediakan papan untuk menayangkan materi di LCD namun untuk LCD nya di lakukan secara lepas pasang, karena mushola tidak hanya di buat pembelajaran namun juga di buat ibadah seperti anak-anak yang melakukan sholat dhuha, sholat dhuhur jamaah dan lain-lain, dan untuk pemeliharaannya saya selaku pemeliharaan sarana dan prasarana mengakui bahwa anak-anak juga cukup membantu 
menjaga alat untuk menunjang proses pembelajarannya." (Bapak Pemelihara Sarana Prasarana, 20187 September)

\section{Hasil Penelitian}

1. Implementasi Moving Class pada Pembelajaran Pendidikan Agama Islam di SMP Negeri 1 Gudo

a. Latar belakang Implementasi Moving Class pada Pembelajaran Pendidikan Agama Islam di SMP Negeri 1 Gudo

Latar belakang di terapkannya Moving Class pada pembelajaran Pendidikan agama Islam adalah di lihat dari pembelajaran yang di lakukan setiap hari di dalam kelas yang tidak berubah ruang atau tidak berganti suasana, menjadikan peserta didik jenuh akan rutinitas yang di lakukan dari pagi sampai siang, Moving Class juga berarti bahwa peserta didik mempunyai kesadaran untuk mendapatkan suatu pengetahuan atau ilmu, maka mereka harus berusaha mencapainya dengan mendatangi ruang yang di sediakan pada pembelajaran pendidikan agama Islam, yakni di mushola.

Menurut Moh Rosyid, sistem Moving Class itu sendiri merupakan suatu usaha untuk mewujudkan proses pembelajaran agar tidak jenuh karena monoton dan rutinitas akibat penyediaan sarana (ruang kelas) yang tidak berubah, tidak berganti, sekaligus memfasilitasi proses pendidikan dengan media pembelajaran yang ideal. ${ }^{6}$

b. Tujuan di adakanya Moving Class pada Pembelajaran Pendidikan Agama Islam di SMP Negeri 1 Gudo.

Tujuan di terapkannya Moving Class di SMP Negeri l Gudo pada pembelajaran pendidikan agama islam yakni, menciptakan sistem pembelajaran yang baru, sehingga mengurangi kejenuhan di dalam kelas serta menjadikan suasana pembelajaran yang aktif dan menyenangkan. Pada pembelajaran pendidikan agama islam banyak sekali teori yang harus di kembangkan lebih jauh, oleh karena itu di harapkan para peserta didik tidak hanya memahami teori dari materi-materi yang di sampaikan oleh guru, namun juga dapat mempraktekkan dan akan di terapkan juga pada kehidupan seharihari.

Hal ini sebagaimana di ungkapkan Djaja Djajuri dalam buku upaya pembelajaran dalam pendidikan dan pengajaran, bahwa tujuan dari sistem Moving Class adalah menciptakan sistem pembelajaran baru dalam pembelajarannya, Terjadinya kerja sama antar siswa, Memulihkan motivasi belajar siswa, Guru dapat mempersiapkan materi secara baik, Meningkatkan efektifitas dan efisien waktu pembelajaran, Meningkatkan disiplin siswa dan guru, Meningkatkan keterampilan guru dalam memvariasikan metode dan media pembelajaran yang di aplikasikan dalam kehidupan sehari-hari, Meningkatkan keberanian siswa dalam bertanya, menjawab dan mengungkapkan pendapat pada setiap mata pelajaran. ${ }^{7}$

\footnotetext{
${ }^{6}$ Moh. Rosyid, Ketimpangan Pendidikan Langkah Awal Pemetaan Patologi Pendidikan Di Indonesia, (Kudus: STAIN Kudus Press, 2006.), 111.

${ }^{7}$ Djaja Djajuri, Dkk, Upaya Pembelajaran Dalam Pendidikan Dan Pengajaran, (Bandung: Remaja Rosdakarya., 1998), 177.
} 
c. Perencanaan Moving Class pada pembelajaran pendidikan agama Islam di SMP Negeri 1 Gudo

Dalam sebuah pembelajaran mengandung tiga proses, yakni perencanaan, penerapan dan evaluasi. Ketiga proses tersebut harus di lakukan secara optimal agar hasil dari sebuah pembelajaran dapat tercapai sesuai dengan tujuan secara efektif dan efisien.

Dalam perencanaan sistem Moving Class pada pembelajaran pendidikan Islam ini guru terlebih dahulu mempersiapkan rencana pelaksanaan pembelajaran, yang mana mempersiapkan materi yang akan di sampaikan pada peserta didik, memilih metode dalam penyampaiannya, dan juga menyusun langkah-langkah selama proses pembelajaran berlangsung, karena dalam sistem moving class ini ada yang di praktekkan maka guru harus benar-benar menyusun waktu dan penyampaian materi secara optimal, karena sesuatu yang di rencanakan secara optimal maka akan berjalan dan berkembang dengan baik.

Menurut Ruajat dalam buku Manajemen Pendidikan menjelaskan mengenai sistem pembelajaran bahwa dalam pembelajaran ada perencanaan yang harus disiapakan sebelum masuk dalam kegiatan pembelajaran. perencanaan adalah proses penetapan dan pemanfaatan sumber daya secara terpadu yang diharapkan dapat menunjang kegiatan dan upaya yang dilaksanakan secara efisien dan efektif dalam mencapai tujuan. Perencanaan dikaitkan dengan penyusunan materi pelajaran, penggunaan media pembelajaran, penggunaan pendekatan dan metode pengajaran, dan penilaian dalam suatu alokasi waktu yang akan dilaksanakan pada masa tertentu untuk mencapai tujuan yang ditentukan. ${ }^{8}$

d. Pelaksanaan Moving Class pada Pembelajaran Pendidikan Agama Islam di SMP Negeri 1 Gudo

Dalam pelaksanaan Pembelajaran Pendidikan Agama Islam dengan sistem Moving Class ini bahwasannya sistem Moving Class ini tidak hanya bisa di lakukan di LAB atau kelas, melainkan bisa di laksanakan di mushola, perpustakaan dan tempat-tempat lain yang masih berhubungan dengan sekolah dan juga mendukung untuk di pakai proses pembelajaran, karena harapan di terapkannya moving class ini untuk membuat pembelajaran menjadi aktif dan menyenangkan.

Dalam pelaksanaannya guru harus mengerti dan memahami bagaimana pelaksanaan sistem moving class, sehingga apa yang menjadi harapan dan tujuan dari sekolah dapat tercapai dan dapat berkembang dengan baik. Moving class tidak hanya di laksanakan di masjid, perpustakaan, dan tempat-tempat yang lain selama masih berhubungan dengan sekolah dan juga sesuai bila di gunakan untuk proses belajar mengajar. Pelaksanaan moving class sangat menuntut siswa untuk selalu berbuat aktif dan keaktifan siswa dalam pelajarannya. ${ }^{9}$ Evaluasi

Akhir dari pembelajaran Pendidikan Agama Islam dengan sistem Moving Class yaitu evaluasi yang ditujukan untuk menilai dan mengukur sejauh mana keberhasilan dalam pembelajaran. Dari segi pemahaman materi maupun dari penerapan praktek. Bisa tersampaikan sesuai target atau tidak. Dengan adanya evaluasi maka guru dan peserta didik mengetahui letak yang harus diperbaiki maupun ditingkatkan untuk keberhasilan dalam pembelajaran.

\footnotetext{
${ }^{8}$ Ajat Rukajat, Manajemen Pembelajaran (Sleman: Deepublish, 2018), 16.

${ }^{9}$ Silberman Melvin L., Active Learning: 101 Cara Belajar Siswa Active, Cet. I (Bandung: Nusa Media Nuansa, 2006), 63.
} 
Mengenai evaluasi sesuai dengan M. Chabib Thoha sebagaimana dikutip oleh Ramayulis, evaluasi merupakan kegiatan yang terencana untuk mengetahui keadaan objek dengan menggunakan instrumen dan hasilnya dibandingkan dengan tolak ukur untuk memperoleh suatu kesimpulan. ${ }^{10} \mathrm{Hal}$ ini didukung pendapat yang dikemukakan oleh Charbonneau dan Raider yang dikutip oleh Trianto dalam bukunya mengatakan bahwa metode evaluasi salah satunya adalah tes dan ujian yang dilakukan baik untuk satu tema pembelajaran maupun untuk beberapa tema. ${ }^{\text {Il }}$

Pada saat tahap evaluasi, guru SMP Negeri l Gudo melakukan pengevaluasian bukan hanya dengan memberikan tes essai atau tes lisan dan juga ujian praktek ketika ulangan harian, tengah semester bahkan akhir semester, namun saat di awal pembelajaran ada tanya jawab seputar materi yang di bahas minggu lalu, dari proses itu guru dapat mengevaluasi sejauh mana tingkat pemahaman peserta didik dalam mengingat materi yang di sampaikan oleh guru. Dan juga ada interaksi antara guru dan peserta didik yang dapat mengetahui apakah materi yang di sampaikan oleh guru dan di praktekkan di sekolah sudah di terapkan apa belum oleh peserta didik dalam kehidupan sehari-hari.

\section{Kesimpulan}

Penerapan sistem moving class pada pembelajaran pendidikan agama Islam di SMP Negeri 1 Gudo merupakan sebuah usaha untuk menciptakan pembelajaran yang baru dan aktif dari beberapa keluhan siswa yang terkadang bosan dengan pembelajaran yang monoton dengan berada di ruang yang sama dari pagi sampai siang. SMP Negeri 1 Gudo memiliki tujuan dalam penerapan sistem moving class ini yaitu bagaimana menjadikan anak tidak hanya sekedar memahami materi di sekolah yang di sampaikan oleh guru, namun juga dapat mengaplikasikan teori dalam kehidupan sehari-hari. Karena pelajaran pendidikan agama Islam banyak teori yang perlu di kembangkan di kehidupan masyarakat.

Faktor yang mendukung sistem moving class pada pembelajaran Pendidikan Agama Islam di SMP Negeri 1 Gudo yaitu dari komitmen seluruh pihak sekolah, dari kepala sekolah, guru PAI dan seluruh staff lainnya, bahwasannya untuk meningkatkan proses pembelajaran aktif serta meningkatkan motivasi belajar siswa, membuat lebih fresh dengan olahraga ringan dengan berpindah tempat belajar dan tidak cepat bosan. Dan juga meningkatkan kualitas guru agar bisa mengembangkan proses pembelajaran dengan memilih metode dan model yang bervariasi dan dapat di sesuai dengan materi yang akan di sampaikan serta menjadikan peserta didik nyaman dalam menerima materi yang di sampaikan. Faktor penghambat sistem moving class pada pembelajaran Pendidikan Agama Islam adalah dari perpindahan yang di lakukan oleh peserta didik yang menyita waktu pembelajaran, bawaan yang banyak dan berat peserta didik yang di bawa saat perpindahan tempat belajar menjadikan waktu kurang disiplin.

\footnotetext{
${ }^{10}$ Ramayulis, Ilmu Pendidian Islam, (Jakarta: Kalam Mulia, 2008), 221.

${ }^{11}$ Trianto, Model-Model Pembelajaran Inovatif Berorientasi Konstruktivistik, (Surabaya: Prestasi Pustaka, 2011), 217.
} 


\section{Daftar Pustaka}

Djajuri, Djaja Dkk. Upaya Pembelajaran Dalam Pendidikan Dan Pengajaran. Bandung: Remaja Rosdakarya., 1998.

Emzir, Metodologi Penelitian Kualitatif Analisis Data. Jakarta: Rajagrafindo Persada, 2014.

Hasan, M., and N. Nikmawati. "Model Pembelajaran Pai Dalam Membentuk Kepribadian Islami Siswa Di Smk Dr Wahidin Sawahan Nganjuk". TA'LIM : Jurnal Studi Pendidikan Islam, Vol. 3, no. 1, Jan. 2020, pp. 1-21.

Melvin, Silberman L., Active Learning: 101 Cara Belajar Siswa Active, Cet. I. Bandung: Nusa Media Nuansa, 2006.

Mulyasa, E. Manajemen Berbasis Sekolah. Bandung; Remaja Rosdakarya, 2002.

Ramayulis, Ilmu Pendidian Islam. Jakarta: Kalam Mulia, 2008.

Rosyid, Moh. Ketimpangan Pendidikan Langkah Awal Pemetaan Patologi Pendidikan Di Indonesia. Kudus: STAIN Kudus Press, 2006.

Rukajat, Ajat. Manajemen Pembelajaran. Sleman: Deepublish, 2018.

Sagala, Syaiful. Kemampuan Profesional Guru Dan Tenaga Pendidikan. Bandung: Alfabet, 2009.

Sugiyono. Metode Penelitian Pendidikan (Pendekatan Kuantitatif, Kualitatif, Dan RひD). Bandung: Alfabeta. 2013.

Trianto, Model-Model Pembelajaran Inovatif Berorientasi Konstruktivistik. Surabaya: Prestasi Pustaka, 2011. 